\title{
Land Suitable Areas Refer to Red Potato Planted on Medium Altitude in Rejang Lebong Bengkulu Province Indonesia
}

\author{
Muhammad Faiz Barchia ${ }^{\#}$, Sukisno ${ }^{\#}$, Heru Widiyono", Satria Putra Utama* \\ \#Soil Science Department, University of Bengkulu, Bengkulu 38371, Indonesia \\ E-mail:faizbarchia@unib.ac.id
}

*Social Economics Department, University of Bengkulu, Bengkulu 38371, Indonesia

\begin{abstract}
The research aims to define potential areas for red potato cultivation in agriculture land in Rejang Lebong District, Bengkulu Province, Indonesia. The research was conducted from February to April 2016 in Rejang Lebong, geographically lying on $102^{\circ} 19^{\prime}-102^{\circ} 57^{\prime}$ Lat., $2^{\circ} 22^{\prime} 07^{\prime \prime}-3^{\circ} 31^{\prime}$ Long., covering of $155,504.81$ ha. Land functions of the district are covered by of Bukit Daun and Bukit Balai Rejang protected forests, Kerinci Seblat National Park, Bukit Kaba Tourism Natural Forest Park, and agricultural cultivation areas. To define land suitability for red potato cultivation in Rejang Lebong areas based on suitable temperature following adaptation experiment results of red potato planted in the medium altitude of Bengkulu Province conducting previously. Spatial analysis for calculating areas of potentially suitable cultivation for red potato was based on overlaying from attributes of the suitable temperature, rainfall, and some soil characteristics. Initial suitable land for potato plantation in Rejang Lebong covered about ha 46,608.98 ha or $29.97 \%$ of the district area with agriculture land function of $11,954.59$ ha or $7.69 \%$ of the district, and forest land use of $34,654.39$ ha or $22.28 \%$ of the district. Based on the overlying suitable land for red potato cultivation over the Rejang Lebong areas was about $108,639.36$ ha lying on agriculture land use of $58,076.64$ ha or $37.34 \%$, and over on conservation and protected forest of 50,562.72 ha or 32.51\%. Potentially suitable land for potato cultivation in Rejang Lebong after correcting with reference of suitable temperature covered double more of the agriculture land than that of the initial. Therefore, in one hand, Rejang Lebong as a central of potato production in Bengkulu has some opportunities to increase potato production for supplying potato demand from surrounding areas in the future. On the other, attempt to increase potato production in Rejang Lebong have to consider environmental aspects and protected conservation forest areas.
\end{abstract}

Keywords — medium altitude; land suitable areas; red potato; conservation forests

\section{INTRODUCTION}

United Nations (UN) reminded that food production for service human life in the world in the form of cereals such as rice, corn, and wheat decrease in the future. The UN aroused all countries to increase food productions and reserves from tuber crops as alternative opportunities to diversify food sources and at the same time to alleviate social poverties. Tuber crops are potential and prospective commodities to support food diversification program in order to reach sustainable food security and sovereignty. Tuber crops can be divided into two major groups: tubers, which is potato and roots including tapioca and sweet potato. Each type of tuber crops has their own characteristics and usage. Tuber and root crops provide a substantial part of the world's food chain and normally growth in the hot and humid region [1].

Improving potato production is one of some efforts to diversify sources of foodstuffs in order to reach self- supporting food supplies for domestic demands. The efforts could be conducted with empowerments of available natural resources such as agro-climatologic compatibilities, soil and land suitability, invention and technologies, and human resources. Potato (Solanum tuberosum L.) is known as an agricultural product in high market values because of lack of suitable lands for its cultivation and usually planted on limited high altitude areas [2]. Today, consumption needs for potato increase rapidly during its production and productivities relatively stagnant. Changes in dietary habits as globalization effects also affect potato demand for domestic consumptions; therefore, expanded agricultural land for potato cultivation is an important role in order to ensure domestic demands [3]. Responses to advanced food industries and human lifestyle in dietary of fast food such as french fries, potato instant, potato skin, or potato chips, domestic demands of potatoes increase every year, and domestic supplies only cover about $10 \%$ of the demands. Rest of great supplies are imported from two big countries; 
China and United States. When fresh potato demands for raw materials of food processing industries increase in the future, domestic fresh potato productions, on the other hand, are not encouraged to cover domestic consumptions, a huge amount of imported potatoes could ruin national food security. Increasing imported raw materials for food processing industries would spend domestic, foreign exchanges which cause weakening the national economies. From that reasons, developments and expansions of potato plantations in some potential areas in Indonesia should be implemented.

Suitable areas for potato plantation usually in high mountainous landscapes in the range of $1.000-3.000 \mathrm{~m}$ altitude, and most suitable land in the range of $1.000-1.300$ $\mathrm{m}$ alt. [4]. The suitable altitudes are quite related to agroclimatology factors such as temperature, air and soil humidity, atmosphere conditions, rainfall and sunlight providing conducive environ for potato growth and development. The temperature of $20-30{ }^{\circ} \mathrm{C}$ was the range of suitable for stem and leaf of potato, and lower than $20{ }^{\circ} \mathrm{C}$ was a conducive environment for tuber initiation and enlargement. High productivities of Potato cultivation planted in areas with the temperature of $15.6-17.8{ }^{\circ} \mathrm{C}$, and soil temperature relatively be lower in the range of $14.0-$ $17.7{ }^{0} \mathrm{C}$ [5]. Soil temperature has an important role in increasing yield. Potato is a plant that its yield affected by soil temperature because of underground tuber production. The best yield of potato was produced when it grew in soil temperature of $21^{\circ} \mathrm{C}$ at night and $24^{\circ} \mathrm{C}$ at noon, and then tuber initiation would be optimum in temperature of $12{ }^{\circ} \mathrm{C}$ [6]. Areas with the maximum temperature of $30{ }^{\circ} \mathrm{C}$ and the minimum temperature of $15{ }^{\circ} \mathrm{C}$ are the very conducive environment for potato growth comparing with potato growth on areas with relatively constant temperature [7].

Agricultural cultivated potato in Bengkulu mostly planted in high altitude areas of Rejang Lebong and Kepahiang Districts at lands of upper $1.000 \mathrm{~m}$ alt. The potato areas are covered by rolling hilly to mountainous landscapes with soils of volcanic ash parent materials [8]. Width areas of potato cultivation in Bengkulu in years of 2011, 2012, 2013, 2014 were as follow 460 ha, 795, ha, 868, ha, and 1.113 ha, with yields of 6.469 tons, 12.611 tons, 12.830 tons, and 16.244 tons, and productivities of 14,06 tons $\mathrm{ha}^{-1}, 15,86$ tons $\mathrm{ha}^{-1}, 14,78$ tons $\mathrm{ha}^{-1}$ and 14,60 tons $\mathrm{ha}^{-1}$. Land productivities for potato plantation in Bengkulu were lower than that of national productivities average in which in the year of those were 15.96 tons ha ${ }^{-1}, 16.58$ tons $\mathrm{ha}^{-1}, 16.02$ tons $\mathrm{ha}^{-1}$, and 17.67 tons $\mathrm{ha}^{-1}$, respectively. Furthermore, the potato productivities in Bengkulu were much lower than that of in West Java, 21.12 tons $\mathrm{ha}^{-1}$ and that of Jambi 21.61tons ha $^{-1}$ [9].

Potato cultivation areas and its productions in Bengkulu were much lower than available potential lands. Available agricultural land in middle altitude lying on $500-1.000 \mathrm{~m}$ alt. of Rejang Lebong are 46,122.05 ha or $29.66 \%$, and in high altitude areas of $>1.000 \mathrm{~m}$ alt. covering $11,954.59$ ha or $7.69 \%$ [10]. These potential areas estimated based on wide of the district, and agro-climatology conditions for horticultural plantation in middle and high altitude areas in Rejang Lebong, however, these lands in some areas have constraints of rolling landscapes. Slope degrees for potato cropping lands correspond on a slope of $<30 \%$, and higher slope degrees were the significant constraint for potato cultivation suitability [11]. However, the constraint factor of slope could be overcome with constructed terrace at the same time improving potential land suitability class.

Potato farms oriented business scales in Bengkulu in the future should cultivate in wide scale areas with suitable land characteristics. For that reason, understanding the wide potential and suitable lands for expanding potato cultivation in Rejang Lebong Bengkulu should be studied based on land mapping evaluation. Land suitability evaluation is a process in an estimation of land suitability level for some land uses with comparing plant growth requirement, and land characteristics or land quality for special land use to potentially available resources [12].

Agricultural expansion on potato plantation should be orientated in the scale of advanced agribusiness and cultivated in suitable areas. To establish potential and suitable land for the development of potato plantations in Bengkulu Province, studies on land evaluation was needed. Basic information for potato plantation development was spatial data about potential and suitable land resources which give important information about land distribution, width areas, land suitability class, constraint factors, and alternative technologies could be implemented related to characteristics and the potential sources. In fact, data and information of suitable land sources and alternative technologies for the development of potato plantation in Bengkulu are still shorten collected.

Study on potato adaptation planted in middle and high altitude Bengkulu landscapes for determining actual land suitability was conducted in Kepahiang District based on constraints factors of agro-climatology, physiological condition, land characteristics, and land quality. The result of research on adaptation of red potato planted in middle and high altitude shown no significantly different between yields of potato planted in middle altitude and yields of that in high altitude areas in Kepahiang district. Also, research on suitability evaluation of land characteristics, land quality, agro-climatology condition for potato plantation was done in some sub-district in Rejang Lebong. Based on these researches, land mapping evaluation for potentially suitable potato cropping in Rejang Lebong was important in order to provide some information for future potato plantation areas in the scale of the high business market.

\section{MATERIAL AND MeTHOD}

The research was conducted at Geospatial Information System Lab, Soil Science Department, the University of Bengkulu from February to April 2016, and field survey was conducted in order to validate data in Rejang Lebong District Bengkulu Province. Agro-climatology data involved rainfall and temperature were collected from Bukit Kaba Vulcanology station, Geo-physic and Meteorology Agency Kepahiang Bengkulu. Rejang Lebong lies on between Bukit Kaba in west border and the Bukit Barisan hilly ranges in the east border, and geographical on $102^{\circ} 19^{\prime}-102^{\circ} 57^{\prime}$ Lat., $2^{\circ} 22^{\prime} 07^{\prime \prime}-3^{\circ} 31^{\prime}$ Long., covering of $155,504.81$ ha (Fig. 1).

The research based on some research before; 1) Correcting Land Suitability with Reference of Suitable Temperature for Red Potato Planted on Medium Altitude in 
Bengkulu Upland [13], and 2) Evaluation of land quality for potatoes field on medium altitude in Bengkulu upland [14].

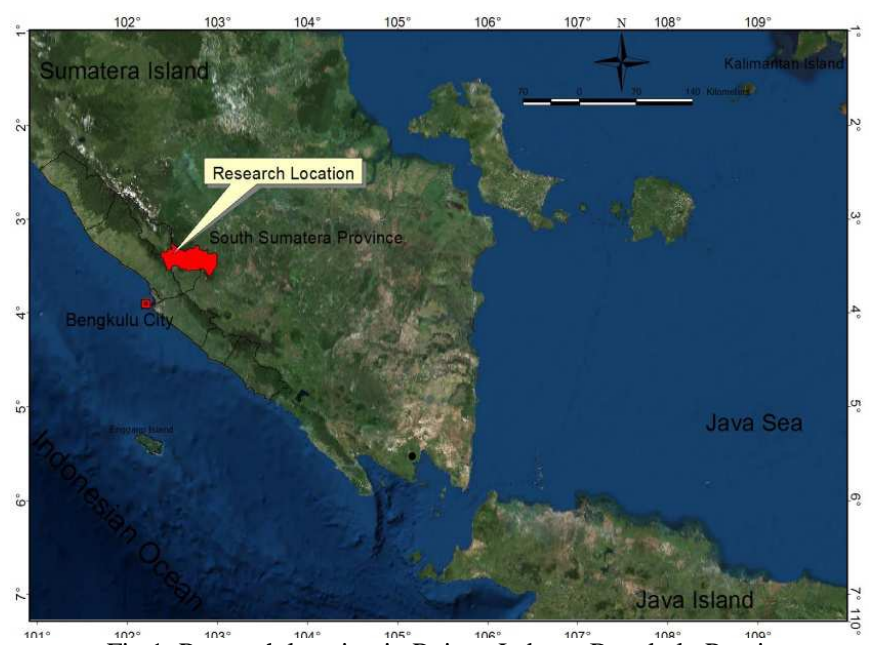

Fig.1 Research location in Rejang Lebong Bengkulu Province

Image interpretation could be performed using a geographic information system (GIS). The use of GIS had evolved into a wide range of knowledge that can be integrated with spatial information. Satellite image interpretation process is the analysis and identification of objects using ArcGIS 10.1 software [15].

In this study, interpretation and extrapolation land suitability for red potato agricultural cultivation in Rejang Lebong district, it was needed spatial data about administration area, elevation contour, land uses and functions, rainfall, etc. Spatial data in the form of ALOS digital data were published by Geospatial Information Agency (BIG) and Ketahun Watershed Management Office (BPDAS Ketahun Bengkulu). The land characteristics digital maps were imposed to figure out land suitability map for potato plantation on middle and high altitude landscape in Rejang Lebong district.

Map of land suitability for red potato plantation was outlined only in agriculturally suitable land, and distributed land suitability on forest areas of Kerinci Seblat National Park, Bukit Kaba Tourism National Forest Park, Bukit Daun and Bukit Balai Rejang Protected Forest, and other natural conservation areas were excluded for potential red potato cultivation areas.

\section{RESULTS AND DISCUSSION}

Rejang Lebong district lies in hilly and mountainous areas, therefore, the landscape of the district covers by sloppy topographical lands. The district is enclosed by Bukit Barisan hilly range and Bukit Kaba Mountain range (Fig 2). Rough textures of the map (Fig. 2) suggest when the lands are cultivated for agricultural purposes, maintaining soil productivities should be implemented soil and water conservation concepts. Agricultural practices on the lands should avoid intensive soil tillages because of the land prone to degradation by erosion, and then threaten sustainable productivities on these lands.
Hilly and mountainous landscapes cover Rejang Lebong District. Therefore, part of the district was assigned as forest areas namely protected forest as water catchment areas, natural forest areas, natural forest tourism park, and national park (Fig. 3). Based on Fig. 3, Northern areas of the Rejang Lebong District covered by Kerinci Seblat National Park, western border covered by areas of Bukit Daun Protected Forest, southern border covered by Bukit Kaba Natural Forest of Tourism Park, and eastern border lies on Bukit Balai Rejang Protected Forest. The total forest areas in Rejang Lebong District cover about 51,747 Ha or about $33.28 \%$ of the district.

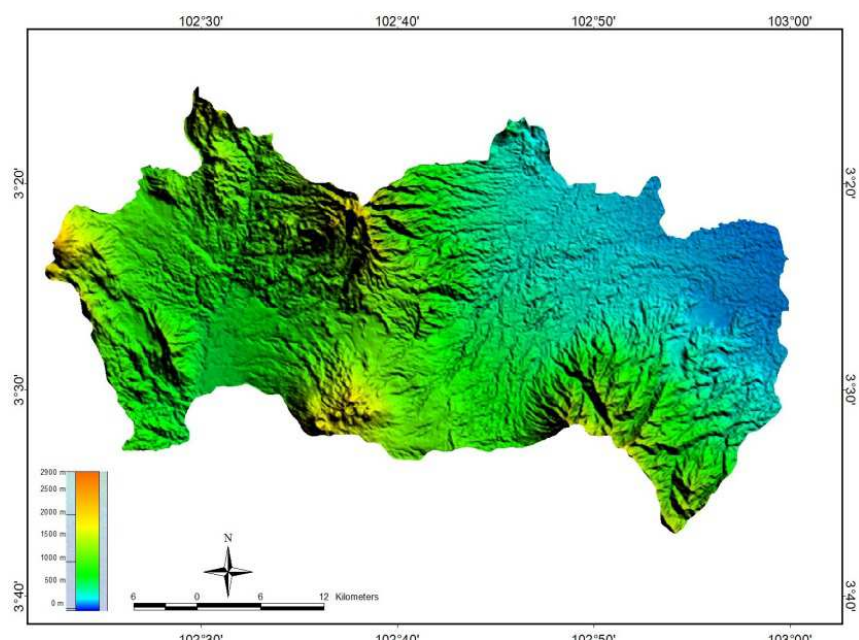

Fig. 2 Rejang Lebong landscape with rolling topographical slope

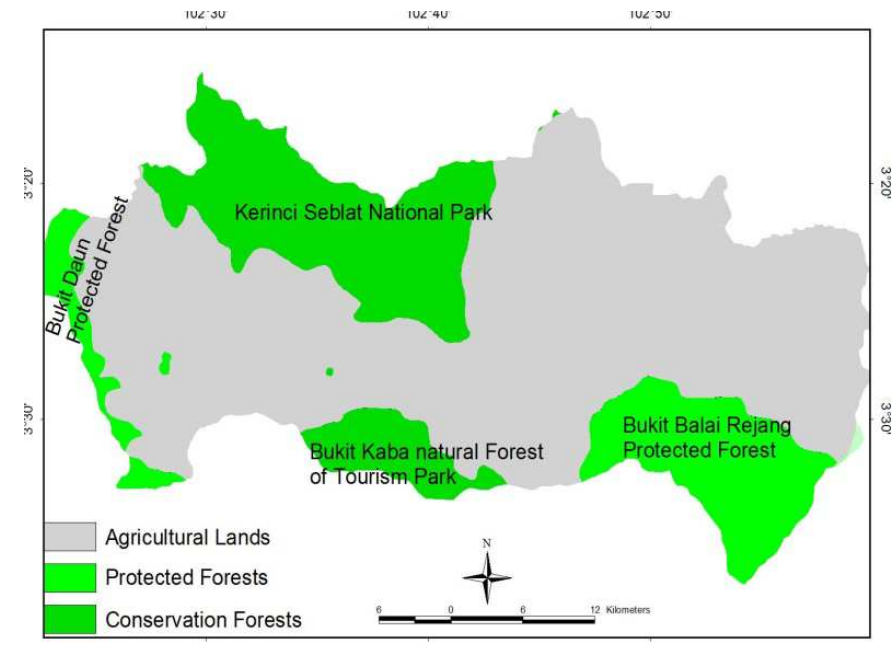

Fig. 3 Landscape of Rejang Lebong based on land use

Based on Fig. 3, agricultural-cultivated areas in Rejang Lebong District lay on valleys and foothill of Bukit Barisan range and Kaba Mountain. Additional information, most areas of the district constitute as upland of Musi watershed and catchment areas of Musi Hydro Power Plant (PLTA Musi). Therefore, sustainability of all forest areas and agricultural-cultivated lands in the Rejang Lebong District had to maintain as service areas for natural water conservation, biodiversities preservation, and continuous water supply for operation of Musi Hydro Power Plant.

Agricultural lands with high topographical contour are fragile to intensive soil tillages. Therefore, agricultural 
activities on these lands should introduce soil conservation tillage systems. Most lands of Rejang Lebong District are covered by landscapes with the high sloppy contour (Fig. 4).

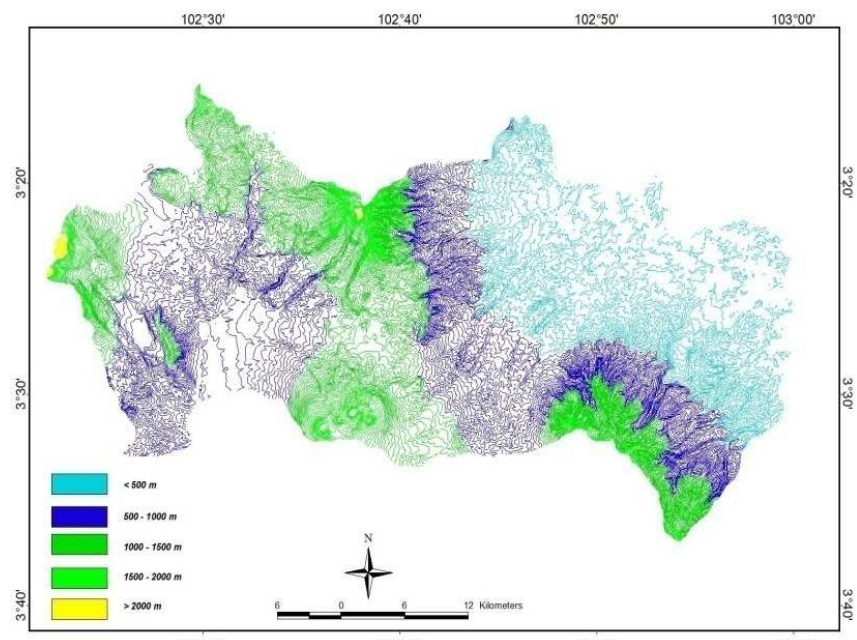

Fig. 4 Rejang Lebong landscape based on topographical contour

The lands with a slope of $<15 \%$ are 55,892 ha or $36.88 \%$ of the district, and the lands with a slope of $15-40 \%$ are 47,712 ha or $31.48 \%$ of the district, and the steepest slope of $>40 \%$ cover 47,972 ha or $31.65 \%$ of the district. Agricultural cultivated areas on Rejang Lebong District lies on slope lands of $<15 \%$ (flat to waving lands) and $15-40 \%$ (surging to hilly landscapes). In fact, lands with the slope of $>40 \%$ (mountainous slope class) were cultivated as agricultural activities in the district. The district is covered by the lands of most waving to mountainous landscapes, fortunately, only $3,632 \mathrm{Ha}$ or $2.40 \%$ of the district as bare lands or sleeping lands.

Soil and land conservation actions are needed on agricultural-cultivated land with sloppy landscapes such as some organic and inorganic mulching applications, swale (guludan) implementation cutting contour lines, and bench terraces constructions. Most agricultural-cultivated areas in Rejang Lebong District should be constructed bench terraces for conservation and maintain sustainable land productivities. However, options for land conservations implemented bench terraces considering local farmer capabilities, these options economically so expensive would be spent. Consequently, few agricultural-cultivated lands in the district are developed with bench terraces.

Potato cultivation fields in Rejang Lebong district mostly on soils with volcanic ash parent materials, andisols, andepts, in which these soils cover about 81,111 ha or $53.51 \%$ of the Rejang Lebong lands. The soils have the depth to very depth profiles involving the depth of $60-90 \mathrm{~cm}$ covering 78,926 ha or $52.07 \%$ and the depth of $>90 \mathrm{~cm}$ covering 59,142 ha or $39.02 \%$ of the district. Areas of red potato plantation generally were cultivated lying on valleys and foothill of Kaba Mountain because of these areas physically fertile with soils of volcanic ash parent materials coming from Kaba Mountain eruption in last long era. Soils of andisols and andepts are classified physically high suitable lands for agricultural-cultivated areas, especially for upland vegetable crops. The soil textures compose of sandy loams or loamy sands in these areas.
Rainfall in this area was $>3,000 \mathrm{~mm} \mathrm{yr}^{-1}$, and the rainfall characteristic was classified as a suitable class (S2) for potato plantation. The temperature in the high-altitude areas was in the range of $18{ }^{\circ} \mathrm{C}$ and $26{ }^{\circ} \mathrm{C}$ with an average daily temperature of $23{ }^{0} \mathrm{C}$. Meanwhile, the temperature in the medium altitude areas was in the range of $19.5^{\circ} \mathrm{C}$ and $28{ }^{\circ} \mathrm{C}$ with the average daily temperature of $24{ }^{\circ} \mathrm{C}$. Land suitability based on the constraint of temperature, in the high altitude areas, was categorized as marginal suitability (S3t), while the land suitability in the medium altitude areas was classified as permanent unsuitability (N2t). Based on the previous study in Kepahiang District Bengkulu Province, statistically there was no significant different between yields of red potato planted in the high altitude areas (Bandung Baru, 1,416 m alt. and Tugu Rejo, 1,135 m alt.) and those planted in the medium altitude areas (Pematang Donok, 650 $\mathrm{m}$ alt. and Kelobak, $500 \mathrm{~m}$ alt). Therefore, potential productivities of red potato planted based on the temperature in the middle elevation areas of Rejang Lebong districts were as same as those in the high altitude areas.

Rejang Lebong District is part of Bengkulu Province lies in upland areas. Rejang Lebong district covers by middle altitude landscape of $500-1000 \mathrm{~m}$ alt. of $62,030.38$ ha or $39.89 \%$ and areas of $>1000 \mathrm{~m}$ alt. of $46,608.98$ ha or $29.97 \%$ of the district (Fig. 5).

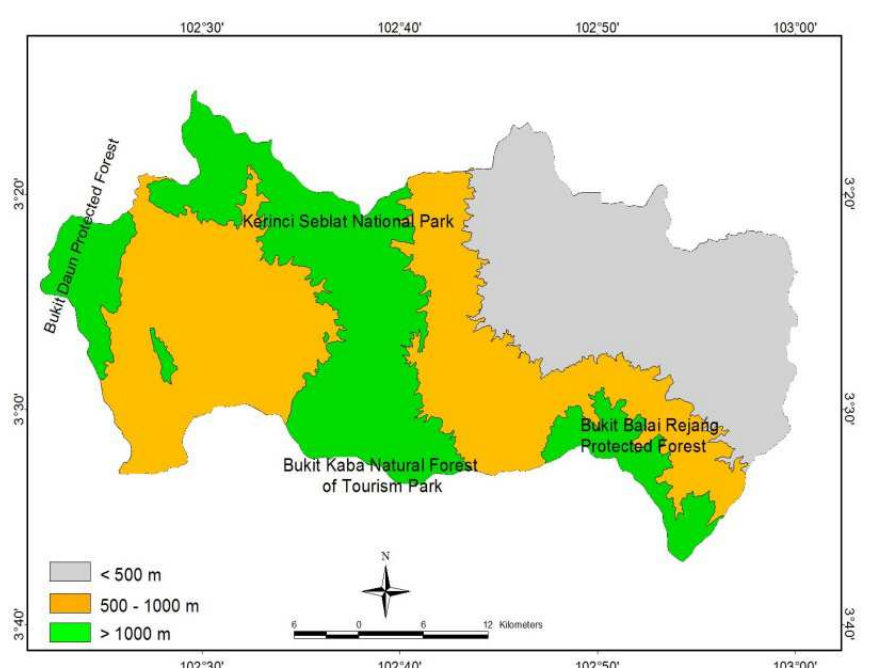

Fig. 5 Landscape of Rejang Lebong based on altitude

Areas of agricultural-cultivated lands in the Rejang Lebong district based on altitudes (Table 1) and areas of forests land uses based on altitudes involved Kerinci Seblat National Park, Bukit Kaba Tourism Natural Forest Park, Bukit Daun and Bukit Balai Rejang Protected Forest, and other natural conservation forests (Table 2).

TABLE I

Areas of Agricultural Cultivated LAND IN REJANG Lebong BASED ON ALTITUDES

\begin{tabular}{|l|l|r|r|}
\hline $\begin{array}{c}\text { Altitudes } \\
\text { Level }\end{array}$ & Altitudes (m) & $\begin{array}{c}\text { Wide Area } \\
\text { (ha) }\end{array}$ & $\begin{array}{c}\text { Wide Area } \\
(\boldsymbol{\%})\end{array}$ \\
\hline Low & $<500$ & $45,680.40$ & 29.38 \\
\hline medium & $500-1000$ & $46,122.05$ & 29.66 \\
\hline High & $>1000$ & $11,954.59$ & 7.69 \\
\hline & sub total & $\mathbf{1 0 3 , 7 5 7 . 0 4}$ & $\mathbf{6 6 . 7 2}$ \\
\hline
\end{tabular}


Based on Table 1, the agricultural-cultivated areas in Rejang Lebong District laying on $<1,000 \mathrm{~m}$ alt reach about $91,802 \mathrm{Ha}$ or $88.5 \%$ of the agricultural lands, and only $11,954 \mathrm{Ha}$ or $11.5 \%$ located on $>1,000 \mathrm{~m}$ alt. Based on references of land suitability, only $11.5 \%$ of the agriculturalcultivated lands in the district suitable for red potato plantation.

TABLE II

AREAS OF ReJANG LEBONG District BASEd on Forest FunCtion AND ALTITUDES

\begin{tabular}{|c|c|c|c|}
\hline Forest Functions & $\begin{array}{c}\text { Altitude } \\
(\mathbf{m})\end{array}$ & $\begin{array}{c}\text { Wide Area } \\
\text { (ha) }\end{array}$ & $\begin{array}{c}\text { Wide Area } \\
(\%)\end{array}$ \\
\hline \multirow{5}{*}{$\begin{array}{l}\text { Natural } \\
\text { Conservation } \\
\text { Forest } \\
\end{array}$} & $<500$ & 0.00 & 0.00 \\
\hline & $500-1000$ & 3281 & בת 0 \\
\hline & & 32.01 & \\
\hline & $>1000$ & 0.00 & 0.00 \\
\hline & sub total & 32.81 & 0.02 \\
\hline \multirow[t]{4}{*}{ Protected Forests } & $<500$ & $1,161.26$ & 0.75 \\
\hline & $500-1000$ & $9,522.37$ & 6.12 \\
\hline & $>1000$ & $9,644.54$ & 6.20 \\
\hline & sub total & $20,328.17$ & 13.07 \\
\hline \multirow[t]{4}{*}{$\begin{array}{l}\text { Kerinci Seblat } \\
\text { National Park } \\
\end{array}$} & $<500$ & 23.79 & 0.02 \\
\hline & $500-1000$ & $6,347.69$ & 4.08 \\
\hline & $>1000$ & $19,092.82$ & 12.28 \\
\hline & sub total & $25,464.30$ & 16.38 \\
\hline \multirow{6}{*}{$\begin{array}{l}\text { Bukit Kaba } \\
\text { Tourism Natural } \\
\text { Forest Park }\end{array}$} & & & \\
\hline & $<500$ & 0.00 & 0.00 \\
\hline & $500-1000$ & 5.46 & 0.00 \\
\hline & $>1000$ & $5,917.04$ & 3.81 \\
\hline & sub total & $5,922.50$ & 3.81 \\
\hline & Total & $155,504.81$ & 100.00 \\
\hline
\end{tabular}

Based on Table 2, the areas of Rejang Lebong District laying on $>1,000 \mathrm{~m}$ alt which locate on forest areas, both on protection forests and conservation forest of 34,654 Ha. From Table 1 and Table II, areas with the altitude of $>1000$ m. cover $46,608.98$ ha or $29.97 \%$ consisting of $34,654.39$ ha, or $22.29 \%$ forest areas involving Kerinci Seblat National Park, Bukit Kaba Tourism Natural Forest Park, Bukit Daun and Bukit Balai Rejang Protected Forest, and other natural conservation forests, and only $11,954.59$ ha, or $7.69 \%$ for agricultural-cultivated land in altitude of $>1000 \mathrm{~m}$ alt.

The widest areas of agricultural-cultivated lands lay on the middle altitude of Rejang Lebong district. The areas of $500-1000 \mathrm{~m}$ alt. covers $62,030.38$ ha or $39.89 \%$ in which $46,122.05$ ha or $29.66 \%$ of the middle altitudes as agricultural-cultivated lands and $15,908.33$ ha or $10.23 \%$ as forest areas (Fig. 6). This showed the distribution of potential lands for potato cultivated fields on medium and high altitude on Rejang Lebong district.

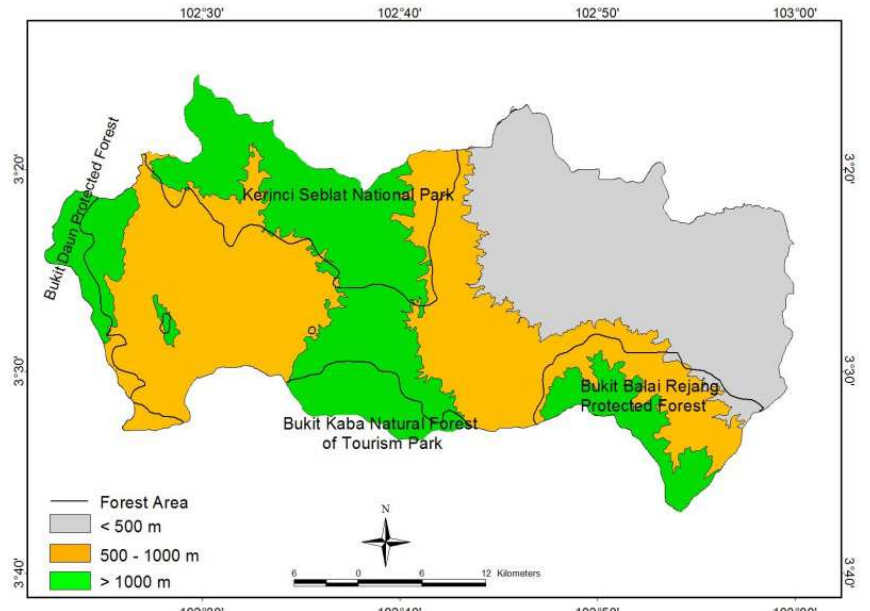

Fig. 6 Potential cultivated agricultural land for potato in Rejang Lebong

In order to improve potato productivity, a new strategy is carried out with developing a new area of potato plants in medium plains $(300-700 \mathrm{~m}$ above sea level) which are provided abundantly in Indonesia [16]. In Buru Island potatoes have been cultivated for hundreds of years at an altitude of 700-1000 meters above sea level [17].

The potential areas for potato cultivation based on altitude lay wider on the forest areas than that on the agriculturalcultivated land. Therefore, if there is no invention on potato cultivars adapted in middle alt, forest areas in Rejang Lebong district would be threatened by the encroachment of traditional farmers. The highest potential of forest lands would face with encroachment by traditional farmers at foothill of Kaba Mountain. This fertile area is part of Bukit Kaba Tourism Natural Forest Park closed to dense settlements and open accessibilities to this forest park. To anticipate the damage to the forest, it is necessary to control and supervision by the Government, the public, and stakeholders.

Potato Cultivated fields in Rejang Lebong district can be expanded to the middle altitude areas, and the medium alt. areas are still available in large amounts. Development of potato planting in medium plain still has some problems. One of a major problem is none of the adaptable cultivars to physical condition especially temperature and humidity. The main problem in potato planting is inadaptability of cultivars in environment stress affecting in very low productivity. Constraints faced in potato cultivation in the plains of the medium among others, temperature, and high light intensity causes high photorespiration (high $\mathrm{CO}^{2}$ release) so that the lower rate of photosynthesis causes low production, as well as pests and diseases, plant pest organisms. The high photorespiration, causing wasteful/release of $\mathrm{CO}^{2}$ from plants, reduces the diffusion of $\mathrm{CO}^{2}$ into the leaf and further decrease the rate of photosynthesis [18]. Potato planted on the lower altitudes would produce the smaller tubers. High temperatures lead to a reduced tuber yield for several reasons, be it by the reduction in the capacity of photosynthesis, be it in an increase of respiration and the assimilate consumption of the leaves. High temperatures also affect the internal tuber quality with a reduction of the dry matter content. This is extremely important, since the greater the dry matter content, the better is the tuber frying quality. High temperatures also promote the increase of the number of tubers with physiological disorders, such as tuber 
cracking, secondary growth and internal spots which depreciate the appearance and reduce the commercial acceptance of the product [19].

However, some potato varieties could grow well on medium altitudes such as Berolina, Dto 33, Desiree [20]. However, in Kenya, Desiree has been largely abandoned due to low yield, poor market, poor taste and susceptibility to late blight [21]. Four cultivars of potato seed, i.e. Granola, Atlantic, Spunta, and Raja could be counted as an adaptable cultivar in medium altitude plain. Potato planted in medium altitude located in Jatinangor at $650 \mathrm{~m}$ above sea level yielded $20.9-25.5$ ton $\mathrm{ha}^{-1}$. Granola is one of potato cultivar enable to adapt on medium altitudes [22]. Two varieties of potato (Granola and Atlantic) planted on agriculturalcultivated lands in South Sulawesi, namely, Gowa, Bantaeng, and Jeneponto located in the medium altitudes of $400 \mathrm{~m}$ (the average daytime temperature/the average night temperature, $\left.30^{\circ} \mathrm{C} / 24^{0} \mathrm{C}\right), 600 \mathrm{~m}\left(29^{\circ} \mathrm{C} / 22^{\circ} \mathrm{C}\right)$, and $800 \mathrm{~m}\left(26^{\circ} \mathrm{C} / 21^{\circ} \mathrm{C}\right)$ gave the average yields in the range of $29.66-34.75$ ton ha $^{-1}$ [23].

Various end-uses of potatoes require specific tuber characteristics and cultivars. Attributes considered in ranking a potato cultivar by farmers are high yield potential, late blight resistance, taste, maturity period, market demand, bacterial wilt resistance, tuber size, and drought tolerance in that order. Natural pigmentation of the skin colour makes a group of varieties with red skin colour very attractive for supermarkets and green markets. In Kenya, different markets prefer different skin colour, tuber shape, and sizes. Redskinned cultivars, which are considered to boil quickly and mash easily are favoured for home consumption. Also, redskinned cultivars are preferred for making chips. Redskinned cultivars have a greater demand in the fresh market probably because they do not turn green when exposed to the light as quickly as white-skinned cultivars [24]. In Bomet district and Meru Central Kenya, red-skinned Dutch Robyjn and red-skinned Asante were predominantly grown by farmers. Cultivar preferences are mostly dictated by the availability of markets, yield potential, and taste [25].

Average Potato yields of six red skin varieties (Kondor, Kuroda, Aladin, Roko, Desiree, and Rudolph) planted in three different locations took place during 2010 and 2011 in the mountainous regions of Montenegro: Nikšić (800 meters of the medium altitude), Kolašin (900 meters of the medium altitude) and Žabljak (1450 meters of the high altitude) were as follow 28.0 tonha $^{-1}, 28.5$ tonha- $^{1}$, and 29.1 tonha $^{-1}$, respectively. Based on the different altitude, there was no significantly different in yields of the potato from each variety [26].

In Rejang Lebong district, another potato variety which could be grown and adapted on medium altitudes with higher temperature was Red Pontiac variety [27]. Based on the previous research, red potato grew well in high production planted on medium altitudes and statistically no significantly different comparing with red potato planted on high altitudes. Average production of Red Pontiac planted on medium altitudes of Kepahiang District was about 20 tons $\mathrm{ha}^{-1}$, and those of higher than potato national productivities.

From the ecological perspective, potato plantations on medium altitudes would be environmentally friendly because agricultural landscapes on medium altitudes are covered by lands of lower slope degree compared with those of high altitudes. A wider range of potato lands in high altitude areas has caused a negative effect on the environment, such as environment damage, due to erosion. Planting potato in highland continually causes a problem such as erosion, declining soil productivity, limited area, and high production costs. Therefore, the extension step development of the potato should be directed to the plain medium that their area is wider than the high plateau, so that in the long term can realize performance for increased production and productivity, and quality of potatoes in a sustainable manner while meeting the needs of the potato national and reduce imports of seeds gradually.

For this reason, some alternative ways need to be applied in order to develop the possibility of growing a potato in medium altitude areas at $500 \mathrm{~m}$ above sea level, where can be found in many areas of Rejang Lebong district which could yield relatively same productions and qualities. However, the potential land availability for agriculturalcultivated fields near the border of the forest areas. Controlling in land expansions for agriculture especially for potato cropping fields should be concerned on borders of the forest areas. The lands in high altitudes of Rejang Lebong District Bengkulu Province are assigned as areas for maintaining hydrological functions, preserving biodiversities, and carbon storages.

\section{CONCLUSIONS}

Expansion of potato cultivated fields could be applied not only to high altitude but also wide areas of medium altitude lands in Rejang Lebong district referring to the planted local red skin potato cultivar. Landscape Rejang Lebong district lies on hilly and mountainous topographical lands. Therefore, expansion of potato fields should understand soil and water conservation methods. Potential agricultural lands for potato cultivated expansion near the border of the forest areas of Kerinci Seblat National Park, Bukit Kaba Tourism Natural Forest Park, Bukit Daun and Bukit Balai Rejang Protected Forest, and other natural conservation forests. Therefore, the agricultural expanded lands, especially for potato fields, have to consider borders of the forest areas.

\section{REFERENCES}

[1] N. I. Nadiah, U. Uthumporn, and Z. A. Syahariza. Effects of microwave heating on potato and tapioca starches in water suspension. IJASEIT. Vol. 6 (1): 61-68. 2016.

[2] M. Winter. Agriculture land use in the era of climatic change: The challenge finding 'Fit for Purpose'. Land Use Policy. 265:5217-5221. 2009

[3] Djoemaijah., M.E.Dwiastuti., D. Setyorini, and J.S.Basuki. Study on a specific technology for potato plated on high altitude. J.Pengkajian dan Pengembangan Teknologi Pertanian Vol 2 (2): 104-110. 2000.

[4] Z Syarif, Characteristic of potato growth on multiple cropping systems with corn in different planting time on medium altitude. Stigma XII (4): 431-436. 2004.

[5] L.A. Manrique, D.P. Bartholomen dan E.E.Ewing. Crop ecology, production and management: growth and yield performance of several potato clones grown at three elevations in Hawai. Crop Sci. 29:363-370. 1989.

[6] V.B. Rubatzky and M.Yamaguchi. World vegetables I. (translated to Indonesia language) Institut.Teknologi Bandung. 1995.

[7] Menzel, C.M. Tuberization in potato at high-temperature responses to gibereline and growth inhibitors. Ann.Bot.(46):259-265. 1980. 
[8] N.C. Deta. Land suitability for red potato grown on medium and high altitude in Kepahiang District Bengkulu Province. Magister Thesis. Department of Natural Resources and Environmental Management. University of Bengkulu. 2010.

[9] Directorate General of Horticulture. Wide cropping areas, production, horticultural productivities in Indonesia. Ministry of Agriculture Republic of Indonesia. 2016.

[10] Bappeda Rejang Lebong. Rejang Lebong District. In Statistics. Bappeda RL-BPS. 2015.

[11] I.A. Wright., R.V. Birnie., A. Malcom., W. Tower., and M. McKeen. The Potential Use of the Land Capability for Agriculture Classification for Determining Support to Disadvantages Areas of Scotland. Macaulay Institute Craigiebuckler Aberdeen AB 15 8QH. 2006.

[12] J.S. Bibby. Land Capability Classification for Agriculture. The MacAulay Landuse Research Institute. Aberdeen. 1991.

[13] M.F. Barchia, S.N. Muin, Mukhtasar, and N.C. Deta. Correcting Land Suitibility with Reference of Suitable Temperature for Red Potato Planted on Medium Altitude in Bengkulu Upland, Jur. Agroekotek. 2 (1):21-26, July 2010.

[14] Zulparmaidi, Sumardi, and M.F. Barchia. Evaluation land quality for potato field on medium altitude in Bengkulu upland. In Proc National Congress of Indonesia Soil Science Society. Surakarta. 2011.

[15] Edwin and Yuzirwan. Evaluation of land use changes in the District Dharmasraya. IJASEIT. Vol. 6(1): 97-103. 2016.

[16] M. Mariana and J.S. Hamdani. Growth and yield of Solanum tuberosum at medium plain with application of paclobutrazol and paranet shade. Agriculture and Agriculture Science Procedia. 9:2630. 2016

[17] H. Kesaulya., Baharuddin., B. Zakaria., Syatrianty, and A. Syaiful. Potential rhizosphere bacteria originated from potato var. Hartapel from Buru Island as plantgGrowth promoters. International Journal of Scientific and Technology Research.4(1) 2015.
[18] M.E. McGiffen, and J. A. Manthey. The role of methanol promoting plant growth: A current evaluation. Hort. Science. 31 (7): 1092-1096. 1996.

[19] E.S. Lambert., C.A.B.P. Pinto, and C.B. Menezes. Potato improvement for tropical conditions: I. Analysis of stability. Crop Breeding and Applied Biotechnology 6: 129-135. 2006.

[20] N. Wicaksana. Phenotype performance from 16 genotypes of potato planted on wetland in medium altitude. Zuriat. 1(12): 15-20. 2001.

[21] C.L.,McArthur. Evaluation, choice and use of potato varieties in Kenya. Social Science Department, Working Paper 1989-1. CIP, Lima, Peru. 1989.

[22] J.S. Hamdami and Y.R. Suradinata. Effect of row intercropping system of corn and potato and row spacing of corn on the growth and yields of Atlantic potato cultivar planted in medium altitude. Asian $J$ Agric. Res 1-9. 2015.

[23] A. Muhibuddin., Z. Razak1, A. Halik, and J. Boling. Growth and production of two varieties of potato in plain medium with methanol supplements. Int.J.Curr.Res.Aca.Rev. 3(5): 330 - 340. 2015.

[24] W.P. Kaguongo., P. Gildemacher., P. Demo., W. Wagoire., P. Kinyae., J. Andrade, and G. Thiele. Farmer practices and adoption of improved potato varieties in Kenya and Uganda. Social Sciences Department, Working Paper 2008-5. International Potato Centre (CIP), Lima, Peru. 2008.

[25] J. Muthoni., H. Shimelis, and R. Melis. Potato production in Kenya: farming systems and production constraints. Journal of Agricultural Science; 5 (5): 182-197. 2013.

[26] Z. Jovovic., A. Verlimirovic., V.Milic, and M. Silj. Examination of some Dutch red skin potato varieties in different agro-ecological condition in Montenegro. IV International Symposium „Agrosym 2013“. 465 - 469. 2013.

[27] Eka-Susianti. Land suitability for potato plantation on the foothill of Kaba Mountain Bengkulu. Thesis S1. Faculty of Agriculture the University of Bengkulu. 2003. 